Journal of Engineering and Applied Sciences 14 (Supplimentary 01): 8473-8478, 2019

ISSN: 1816-949X

(C) Medwell Journals, 2019

\title{
Performance of Moving Bed Biofilm Reactor for Ammonia Nitrogen Removal from Surface Water as Pre-Treatment Process
}

\author{
S. Rhefa Fauza, Setyo S. Moersidik and Sandyanto Adityosulindro \\ Departement of Civil Engineering, Environmental Engineering, Program \\ Universitas Indonesia, 16424 Depok, West Java, Indonesia \\ rhefa.fauza@ui.ac.id
}

\begin{abstract}
High concentration of $\mathrm{NH}_{3}-\mathrm{N}$ on surface water could cause problems in drinking water treatment. The raw water in this condition usually polluted by $\mathrm{NH}_{3}-\mathrm{N}$ and organic matter. In order to remove those pollutant a pre-treatment process is needed. This treatment generally uses chemical and physical processes such as chlorination and activated carbon that produce harmful byproducts. Moving Bed Biofilm Reactor (MBBR) is one of the solutions developed to reduce the nutrient and organic levels in raw water. The research was conducted using a bench-scale reactor with $6 \mathrm{~L}$ capacity operated with Kaldness $\mathrm{K} 1$ as the medium and oxygen supply of $7 \mathrm{~L} / \mathrm{min}$. Reactor performance is assessed based on parameter removal efficiency with variations of Hydraulic Loading Rate (HRT) which were 1, 1.5 and $2 \mathrm{~h}$. After operated for 48 days, the result showed that the optimum residence time is $1.5 \mathrm{~h}$ with the ability to remove Chemical Oxygen Demand (COD) and $\mathrm{NH}_{3}-\mathrm{N}$ $51.8 \% \pm 0.2$ and $54.3 \% \pm 0.28$, respectively. Batch experiment were performed to study nitrification kinetics. It showed that the kinetics of the ammonia removal rate in MBBR takes place at zero order with a rate constant removal of $0.0056 \mathrm{~g} / \mathrm{m}^{2}$ day. The results showed that by providing contaminants with high concentrations, the reactor could achieve higher removal efficiency.
\end{abstract}

Key words: Moving bed biofilm reactor, pre-treatment, raw water, COD, ammonia, hydraulic retention time

\section{INTRODUCTION}

Ministry of Environment in 2015 stated that $68 \%$ of river in Indonesia were heavily polluted. In addition, based on the quality monitoring of the Jakarta river conducted by Regional Environmental Agency (BPLHD) in 2015, the average river in Jakarta area has also, entered a heavily polluted status. According to a research conducted by Sabila (2017), agricultural activities and housing occupy the majority of area around Pesanggrahan watershed. This activity gives great contribution to the amount of detergent waste, phosphate, ammonia nitrogen and organic material that enters the water body. The concentration of organic pollutants and amonia which exceeded the threshold based on Government Regulations No. 82 of 2001 will make it difficult for water treatment plants to treat raw water. Because conventional WTP is not designed to eliminate organic parameters and ammonia (Nugroho and Said, 2011).

In order to eliminate these contaminants and to meet the environmental standards, a pre-treatment is required before conventional process. The pre-treatment that is usually used in WTP is pre-chlorination process which can produce carcinogenic byproducts such as trihalomethane and chlorophenol (Nugroho and Said, 2011). In addition, ammonia nitrogen residue can be a substrate of nitrifying bacteria to grow back during the water distribution process which can destroy the bio-stability of drinking water (Regan et al., 2003).

In order to reduce the level of organic compounds and ammonia without the use of chemicals and excessive operational costs, alternative technology that can be used is biological processes. Moving Bed Biofilm Reactor (MBBR) is one of the solutions developed to reduce nutrient and organic levels in raw water and wastewater. According to Zhang et al. (2013), this system has advantages over other biological pre-treatment process such as aerated filter, biological contact oxidation and membrane bioreactor because it does not cost much does not require a lot of space and is quite efficient in removing pollutant parameters. Because of these advantages, MBBR technology has been widely applied to treat wastewater and surface water. Research on the use of MBBR as a pre-treatment unit for surface water treatment was first carried out by Xiangyang (2009) using a

Corresponding Author: Setyo S. Moersidik, Departement of Civil Engineering, Environmental Engineering, Program Universitas Indonesia, 16424 Depok, West Java, Indonesia rhefa.fauza@ui.ac.id 
pilot-scale reactor. It was proven that MBBR could remove ammonia concentration from the Yellow River sample water in China at $61.6 \%$ and COD by $11.53 \%$. Another study was also, carried out by Zhang et al. (2013) for low polluted water using Taihu River sample water in China. The study proved that the level of ammonia removal efficiency in the reactor reached $71.4 \pm 26.9 \%$ depending on the influence of temperature, organic load and residence time.

The aim of research: This research was conducted to analyze the performance of MBBR technology in removing organic contaminants and ammonia in the Pesanggrahan River as a pre-treatment technology to meet the class 1 quality standard based on Indonesian Government Regulations No. 82 of 2001.

\section{MATERIALS AND METHODS}

Raw water: The raw water used was from the Pesanggrahan River at Cinere observation point. The water sample used contained a high $\mathrm{NH}_{3}-\mathrm{N}$ concentration with a range of $0.08-1.04 \mathrm{mg} / \mathrm{L}$ and a COD concentration of $24.3-106.2 \mathrm{mg} / \mathrm{L}$. Meanwhile, the concentration of $\mathrm{pH}$, $\mathrm{DO}$ and temperature of the sample water were respectively, $7.01-7.53 ; 4.2-8.1 \mathrm{mg} / \mathrm{L}$ and $27-30.3^{\circ} \mathrm{C}$. When compared to the quality standard based on Indonesian Government Regulations No. 82 of 2001, this water belongs to class 3 which is only suitable for a source of water for fisheries and livestock.
Experimental setup: This research was conducted using bench scale with the scheme of MBBR that is shown on Fig. 1. Kaldness K1 was used as a medium because it had large surface area $\left(500 \mathrm{~m}^{2} / \mathrm{m}^{3}\right)$, thus, facilitating the attachment and growth of biofilms in the media. The MBBR reactor used had a volume of $6 \mathrm{~L}(20 \times 15 \times 25 \mathrm{~cm})$ based on plexiglass. The design of the reactor referred to the study by Zhang et al. (2014) with a modification of the addition of a pre-sedimentation zone. Pre-sedimentation zone was made to reduce TSS concentrations before the water was treated using Kaldness K1. The high concentration of TSS would reduce pollutant removal efficiency in biofilm system because it could clog the media, so that, it would inhibit biofilm growth (Nugroho and Said, 2011). Aeration was given through diffusor with a capacity of $7 \mathrm{~L} / \mathrm{min}$. The water flowing process during the operation was carried out continuously using a peristaltic pump with a flow rate of $100,66.7$ and $50 \mathrm{~mL} / \mathrm{min}$. This research was conducted with three variations of detention time which was $1,1.5$ and $2 \mathrm{~h}$.

Analytical techniques: The laboratory tests conducted to determined the concentration of $\mathrm{COD}$ and $\mathrm{NH}_{3}-\mathrm{N}$ from reactor's effluent, according to the National Standard of Indonesia (SNI 6989.72:2009). While both parameters, DO and $\mathrm{pH}$ were measured by $\mathrm{DO}$ and $\mathrm{pH}$ meter, according to (SNI 06-6989.23: 2005).

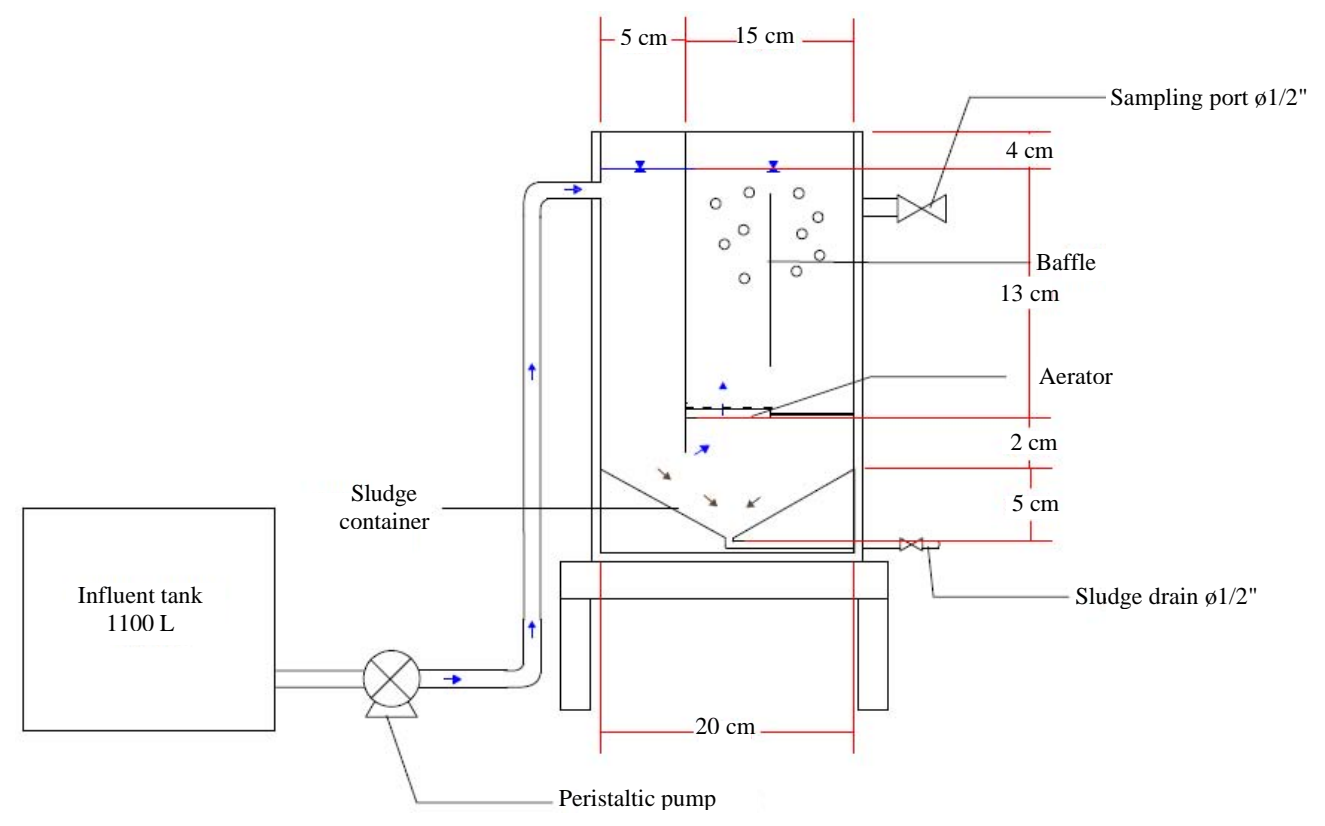

Fig. 1: Schematic of the bench scale Moving Bed Biofilm Reactor (MBBR) 


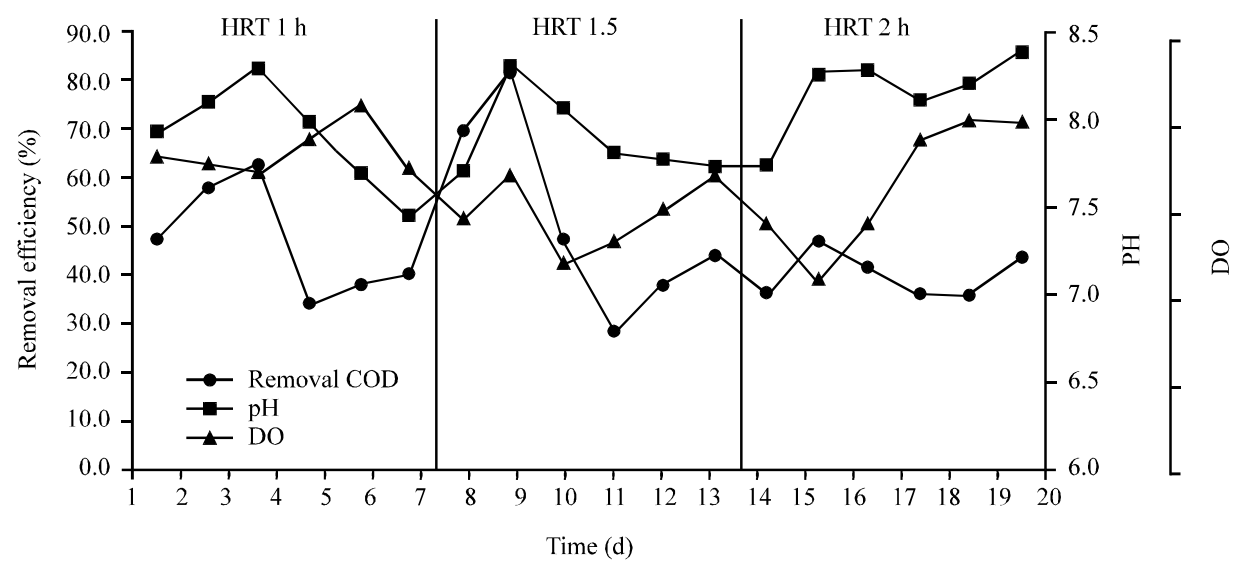

Fig. 2: $\mathrm{COD}$ removal efficiency, $\mathrm{DO}$ and $\mathrm{pH}$ during operational period

\section{RESULTS AND DISCUSSION}

Start-up period: Seeding process was carried out to grow bacteria in the media by adding an inoculum in the form of activated sludge from the oxidation ditch unit of the Jababeka WWTP with an MLVSS concentration of $6232.1 \mathrm{mg} / \mathrm{L}$. The system was operated by a batch method to support the formation of a biofilm layer with a flow rate of $100 \mathrm{~mL} / \mathrm{min}$. During the seeding process, a control over DO concentration above $2 \mathrm{mg} / \mathrm{L}$ was carried out (Wang et al., 2006), $\mathrm{pH}$ of 6.5-8.5 and temperature of $25-35^{\circ} \mathrm{C}$ (Tchobanoglous, 1981) to support bacterial growth. The inoculation process was completed in 17 days, marked by the formation of a biofilm layer and the reach of steady state condition as indicated by the increasement in removal efficiency from $34-55 \%$ (days 10-17).

After the seeding process was completed, an acclimatization process was carried out as a process of microbial adaptation to the water of Pesanggrahan River. The process was carried out gradually for 10 days until up to $100 \%$ of the reactor volume was filled with Pesanggrahan River water. The acclimatization process was divided into four stages based on the composition of the reactor loading. Phasing was carried out with a loading percentage of $25 \%$, then it was continued with an increase of multiples of $25 \%$ every 2 or 3 days. Changes in load were carried out when the percentage of efficiency had increased because it was assumed that the bacteria in the reactor were familiar with the load given.

Performance of COD and $\mathrm{NH}_{3}-\mathrm{N}$ removal through MBBR: Elimination performance of $\mathrm{COD}$ and $\mathrm{NH}_{3}-\mathrm{N}$ on MBBR was shown in Fig. 2 and 4. The results showed that under conditions of $\mathrm{DO}=7-8 \mathrm{mg} / \mathrm{L}$ and $\mathrm{pH}=7.4-8.4$, the system could reach removal efficiency up to $88.3 \%$

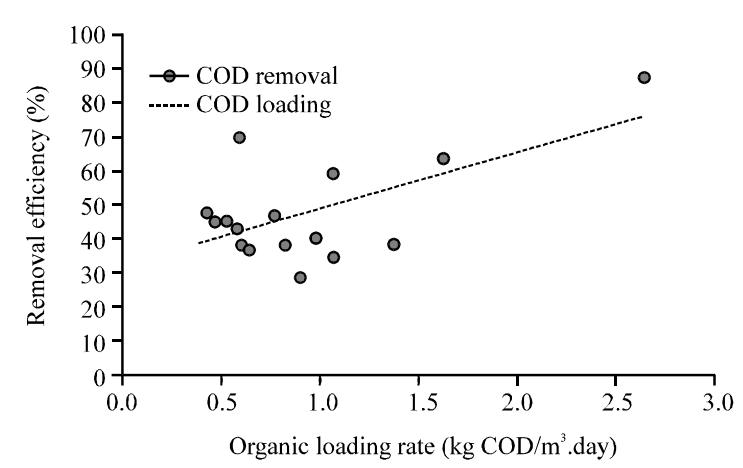

Fig. 3: COD removal rates versus $C O D$ loading rates in the MBBR system

and $91.4 \%$, respectively. The level of COD efficiency that had not been optimal was achieved at $1 \mathrm{~h}$ of HRT with the removal range of $34.46-63.42 \%$. This was because the bacteria were still in the adjustment stage to the operational conditions of the reactor. In addition, there was a significant fluctuation in $\mathrm{pH}$ and there was a drop in DO from 7.8-7.7 mg/L. Based on a research conducted by Ghanizadeh and Sarrafpour (2001), pH conditions had a significant effect on COD removal. Therefore, it was necessary to maintain $\mathrm{pH}$ because heterotrophic bacteria grew optimally in the $\mathrm{pH}$ range 7-8 (Hoang, 2013). Optimal removal efficiency was reached at $1.5 \mathrm{~h}$ of HRT with removal of $88.26 \%$, DO concentration and $\mathrm{pH}$ condition of $7.7-7.7 \mathrm{mg} / \mathrm{L}$ and $7.72-8.33$, respectively (days $8-13$ ).

Based on Fig. 3, it was known that the reactor was able to process organic loads of more than $2.5 \mathrm{~kg}$ $\mathrm{COD} / \mathrm{m}^{3}$ day. With an average organic load of $0.9 \mathrm{~kg}$ $\mathrm{COD} / \mathrm{m}^{3}$ day, the removal range was $28.5-88.3 \%$. Previous research explained that the higher the organic load was the higher the COD removal efficiency became (Odegaard et al., 1994). This was due to the consumption 


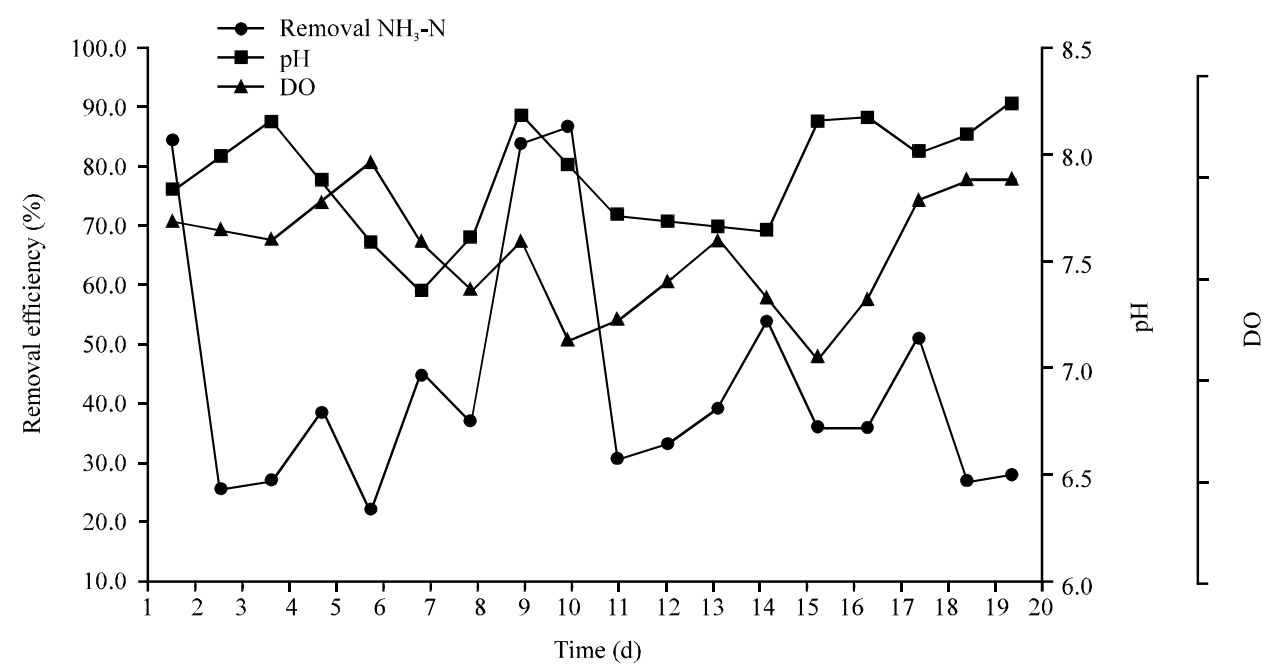

Fig. 4: $\mathrm{NH}_{3}-\mathrm{N}$ removal efficiency, $\mathrm{DO}$ and $\mathrm{pH}$ during operational period

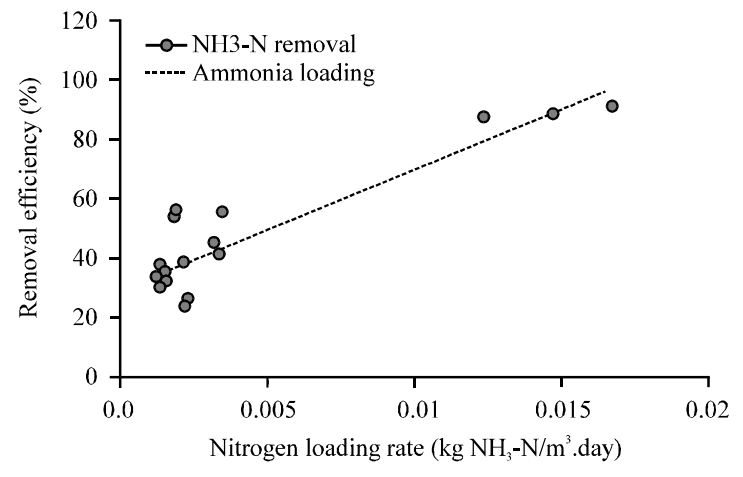

Fig. 5: $\mathrm{NH}_{3}-\mathrm{N}$ removal rates versus ammonia loading rates in the MBBR system

of carbon material by bacteria which caused an increase in removal efficiency as the organic load was increased (Fig. 4). For $\mathrm{NH}_{3}-\mathrm{N}$ removal, bacteria were very dependent on DO concentration. This was because DO was a co-substrate in the nitrification process because it was able to carry out the nitrification process, an oxygen concentration of more than $1 \mathrm{mg} / \mathrm{L}$ was needed (Zafarzadeh et al., 2010). If the oxygen concentration was lower, it would be the limiting factor and the nitrification could run slower. In this study, the $\mathrm{pH}$ range was maintained to be always at 6.5-8.5 because the rate of nitrification decreased significantly when the $\mathrm{pH}$ was below 6.8. Specifically, the optimum $\mathrm{pH}$ range for Nitrosomonas and Nitrobacter bacteria were 7.9-8.2 and $7.2-7.6$, respectively. On the first 3 days, it was seen that the $\mathrm{pH}$ decreased, this was because alkalinity was consumed at the initial stage of the nitrification process which caused a decrease in $\mathrm{pH}$.
Based on Fig. 5, it could be seen that the higher the ammonia load, the higher the efficiency of ammonia removal becomes. Maximum efficiency was reached at $91.4 \%$ with a load of $0.017 \mathrm{~kg} \mathrm{COD} / \mathrm{m}^{3}$.day. While the lowest efficiency $(22.5 \%)$ was reached when the ammonia load being treated was at the minimum point, i.e., $0.0012 \mathrm{~kg}$ $\mathrm{COD} / \mathrm{m}^{3}$ day. Based on Ødegaard's study in 1999, in order that nitrification process could take place, it would require a load of more than $4 \mathrm{~g} / \mathrm{m}^{2}$.day and an oxygen concentration above $6 \mathrm{mg} / \mathrm{L}$. These results were also, supported by Zafarzadeh et al. (2010) which showed that with a load range of $0.1-4.43 \mathrm{~g}-\mathrm{N} / \mathrm{m}^{2} . \mathrm{d}$, the highest removal was $93 \%$ reached at the highest load (Fig. 6).

Determination of optimal detention time referred to the removal efficiency of $\mathrm{COD}$ and $\mathrm{NH}_{3}-\mathrm{N}$ with variations in HRT. In order to identify the data distribution and minimum removal, boxplots were used to adjust the effluent to quality standard. When viewed from the median, there was no significant difference. If the median value had similarities, the comparison would be seen from Q3 and whisker length at the top of the box (Ferreira et al., 2016). For the COD parameter removal, $1.5 \mathrm{~h}$ of HRT had a $Q 3$ value and the maximum value was higher when compared to $2 \mathrm{~h}$ of HRT. This indicates that the removal rate of $1.5 \mathrm{~h}$ of HRT could reach a high value of $81.7 \%$. In addition, the average HRT effluent of $1.5 \mathrm{~h}$ was closer to the target of class 1 Government Regulations No. 82 of 2001. At $\mathrm{NH}_{3}-\mathrm{N}$ removal, there was also, a median similarity, so that, the comparison seen from Q3 and whisker length at the top of the box was determined to be $1.5 \mathrm{~h}$ as optimal detention time (Fig. 6).

Batch experiments: After obtaining the optimum detention time of MBBR, a batch experiment was 

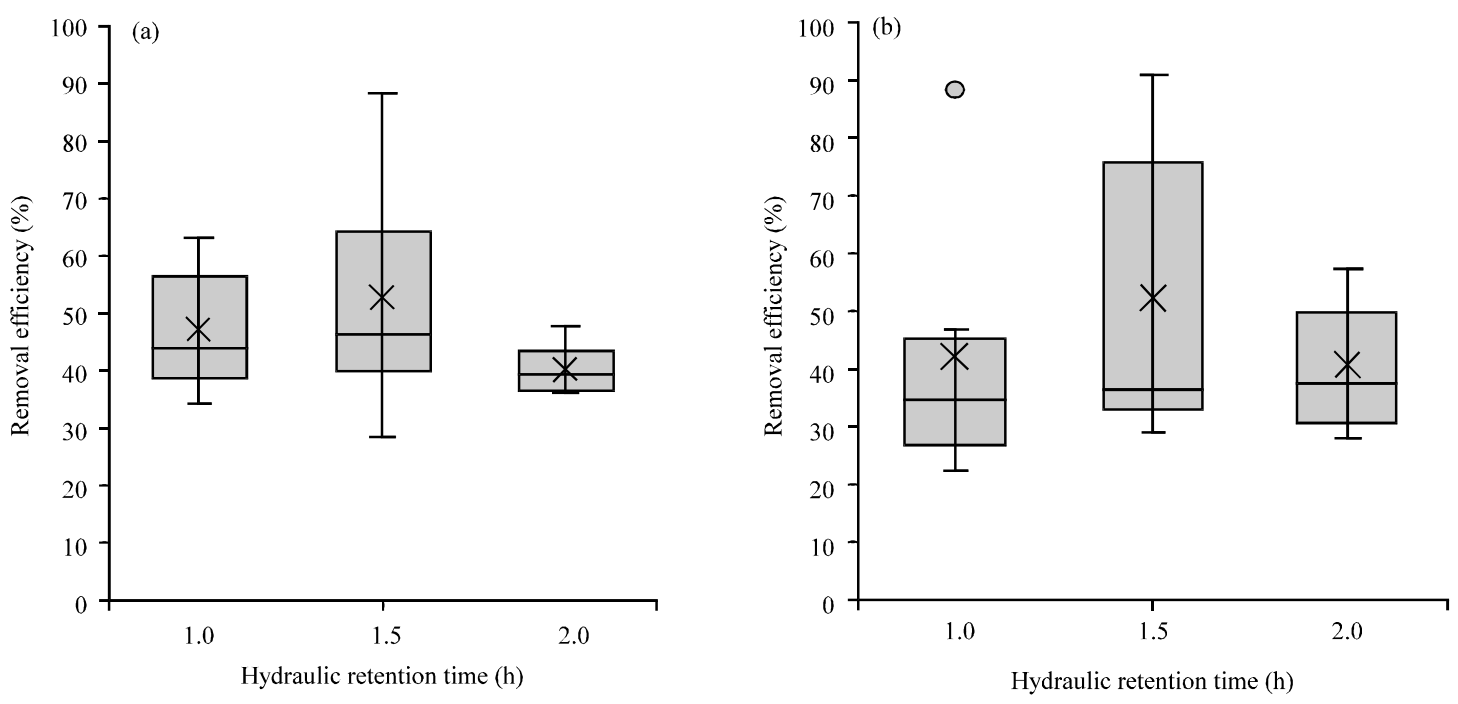

Fig. 6: a) Box plot removal efficiency of $\mathrm{COD}$ and b) $\mathrm{NH}_{3}-\mathrm{N}$

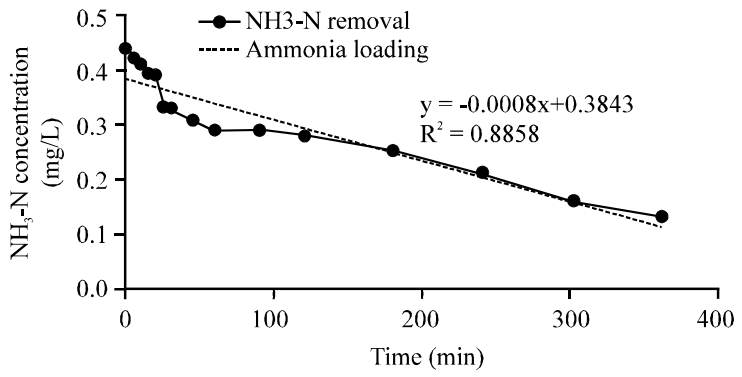

Fig. 7: $\mathrm{NH}_{3}-\mathrm{N}$ removal rates versus ammonia loading rates in the MBBR system

conducted to determine the $\mathrm{NH}_{3}-\mathrm{N}$ removal kinetics on MBBR. During this experiment, the same treatment was given to the compounds as it was given during continuous trials with a detention time of $1.5 \mathrm{~h}$. At the start of the batch trial, tests were carried out on the concentrations of $\mathrm{NH}_{3}-\mathrm{N}$ to determine the initial concentration of ammonia nitrogen in water sample used. The observation was carried out for $4 \mathrm{~h}$ with initial $\mathrm{NH}_{3}-\mathrm{N}$ concentration level of $0.44 \mathrm{mg} / \mathrm{L}$ (Fig. 7).

Based on Fig. 7, it is known that the kinetics of ammonia removal rate in MBBR takes place at zero order with a removal rate constant of $0.0056 \mathrm{~g} / \mathrm{m}^{2}$.day. Zero order removal rate constant would increase significantly as the load was being processed, hence, the zero order removal rate constant reflected the maximum reaction rate limited by bacteria metabolism (Ahnen et al., 2015). Previous research had also, explained this condition, the nitrification rate showed a strong relation to the ammonium loading rate in aerobic conditions (Zafarzadeh et al., 2010).

\section{CONCLUSION}

According to this research, moving bed biofilm reactor as a pre-treatment process was quite effective in removing $\mathrm{COD}$ and $\mathrm{NH}_{3}-\mathrm{N}$ from micro-polluted surface water. In order to evaluate the optimum residence time of $M B B R$, variations in residence time were used which are $1,1.5$ and $2 \mathrm{~h}$. The reactor reached the maximum removal efficiency of $88.3 \%$ for COD removal and $91.4 \%$ for $\mathrm{NH}_{3}-\mathrm{N}$ at $1.5 \mathrm{~h}$ of detention time. In addition, the effluent from the detention time had met the class 1 quality standard based on Government Regulations No. 82 of 2001.

The optimum residence time reached for the MBBR system was $1.5 \mathrm{~h}$ with 48 days of operating time and removal efficiency $51.8 \% \pm 0.2$ for COD and $54.3 \% \pm 0.28$ for $\mathrm{NH}_{3}-\mathrm{N}$. During the research process, the oxygen concentration was always above $4 \mathrm{mg} / \mathrm{L}$. This concentration is sufficient to provide conditions where there is a perfect nitrification process, hence, ammonia nitrogen contained in river water will be converted into nitrite and nitrate and can also, prevent competition between autotrophic and heterotrophic bacteria. MBBR is the appropriate pre-treatment unit for conventional water treatment process in Jakarta because it can enhance the removal of different pollutants and does not require much space.

\section{ACKNOWLEDGEMENT}

This study was supported by Universitas Indonesia under the study of PITTA 2018 funding scheme with contract No. $2529 / \mathrm{UN} 2 . R 3.1 / \mathrm{HKP} .05 .00 / 2018$. 


\section{REFERENCES}

Ahnen, M.V., L.F. Pedersen, P.B. Pedersen and J. Dalsgaard, 2015. Degradation of Urea, Ammonia and Nitrite in moving bed biofilters operated at different feed loadings. Aquacult. Eng., 69: 50-59.

Ferreira, J.E.V., R.M. Miranda, A.F. Figueiredo, J.P. Barbosa and E.M. Brasil, 2016. Box-and-whisker plots applied to food Chemistry. J. Chem. Educ., 93: 2026-2032.

Ghanizadeh, G. and R. Sarrafpour, 2001. The effects of temperature and $\mathrm{PH}$ on settlability of activated sludge flocs. Iran. J. Public Health, 30: 139-142.

Hoang, V., 2013. MBBR Ammonia removal: An investigation of nitrification kinetics, biofilm and biomass response and bacterial population shifts during long-term cold temperature exposure. MSc Thesis, Department of Civil Engineering, University of Ottawa, Ottawa, Canada.

Nugroho, R. and N.I. Said, 2011. [Improvement of drinking water company quality (PAM) with biofiltration (In Indonesian)]. J. Environ. Technol., 12: 121-129.

Odegaard, H., B. Rusten and T. Westrum, 1994. A new moving bed biofilm reactor applications and results. Water Sci. Technol., 29: 157-165.

Regan, J.M., G.W. Harrington, H. Baribeau, R.D. Leon and D.R. Noguera, 2003. Diversity of nitrifying bacteria in full-scale chloraminated distribution systems. Water Res., 37: 197-205.
Sabila, M.F., 2017. The effect of land use changes in ciliwung and Pesanggrahan watershed. Ph.D Thesis, Bogor Agricultural University, Bogor, Indonesia.

Tchobanoglous, C., 1981. Wastewater Engineering: Collection and Pumping of Wastewater. McGraw-Hill Book, New York, USA., Pages: 432.

Wang, X.J., S.Q. Xia, L. Chen, J.F. Zhao, N.J. Renault and J.M. Chovelon, 2006. Nutrients removal from municipal wastewater by chemical precipitation in a moving bed biofilm reactor. Process Biochem., 41: 824-828.

Xiangyang, S., 2009. Enhanced treatment of polluted surface water from Yellow river (China) with biooxidation as pretreatment: Pilot scale studies. Desalin. Water Treat., 9: 59-65.

Zafarzadeh, A., B. Bina, M. Nikaeen, H.M. Attar and M.H. Nejad, 2010. Performance of moving bed Biofilm reactors for biological nitrogen compounds removal from wastewater by partial nitrification-denitrification process. Iran. J. Environ. Health Sci. Eng., 7: 353-364.

Zhang, S., Y. Wang, W. He, M. Wu and M. Xing et al., 2013. Responses of biofilm characteristics to variations in temperature and $\mathrm{NH}^{+}-\mathrm{N}$ loading in a moving-bed biofilm reactor treating micro-polluted raw water. Bioresource Technol., 131: 365-373.

Zhang, S., Y. Wang, W. He, M. Wu and M. Xing et al., 2014. Impacts of temperature and nitrifying community on nitrification kinetics in a moving-bed biofilm reactor treating polluted raw water. Chem. Eng. J., 236: 242-250. 